\title{
The Effects of Auditory, Intellectually, and Repetition (AIR) Learning Model to Problem Solving Skills of the Students Grade XI IPA of SMAN 2 Banguntapan on the Subject of Kinetic Theory of Gases
}

\author{
Nilatul Khoeriyah*, Widayanti \\ Physics Education Department, Faculty of Science \& Technology, Universitas Islam Negeri Sunan Kalijaga, \\ J1. Marsda Adisucipto Yogyakarta 55281, Indonesia \\ *Email: nilatulkhoeriyah@yahoo.co.id
}

\begin{abstract}
Khoeriyah N, Widayanti. 2017. The Effects of Auditory, Intellectually, and Repetition (AIR) Learning Model to Problem Solving Skills of the Students Grade XI IPA of SMAN 2 Banguntapan on the Subject of Kinetic Theory of Gases. Proc Internat Conf Sci Engin 1: 225-228. The purpose of this research is to know the effects of Auditory, Intellectually, and Repetition (AIR) learning model on student's problem solving skills and to knows the problem solving skills enhancement students who take the learning use Auditroy, Intellectually, and Repetition (AIR). This research is a quasi-experimental reasearch (quasi experiment) with pretest-posttest control group design. The independent variable in this research is Auditory, Intellectually, and Repetition (AIR) learning model and the dependent variable is student problem solving skills. The population in this research are class XI IPA SMA N 2 Banguntapan. The sampling technique is simple random sampling as experiment class is XI IPA 2 and as control class is XI IPA 3. The research instrument used a pretest-posttest question sheet. Data analysis technique used statistical parametric of T test and normalized gain ( $N$-Gain) test. The result showed that (1) Auditory, Intellectually, and Repetition (AIR) learning model influence on problem solving skills of students on the subject of theory kinetic gas (level of significance (sig. 2-tailed) $=0,000<\alpha=0,05$, therefore $\mathrm{H}_{0}$ is rejected and $\mathrm{H}_{\mathrm{a}}$ is received), (2) Auditory, Intellectually, and Repetition (AIR) model learning can improve students' problem solving skills on the subject of theory kinetic gas $(N$-Gain experimental class $=0,886$ (high) $>N$-gain control class $=0,662$ (medium).
\end{abstract}

Keywords: Auditory, Intellectually, and Repetition (AIR) learning model, problem solving skills, and Kinetic Theory of Gases

\section{INTRODUCTION}

SMA N 2 Banguntapan located in Glondong, Wirokerten, Banguntapan, Bantul, Yogyakarta. SMA N 2 Banguntapan located in strategic locations because it is lie adjacent Giwangan bus station and the Wirokerten village office. The facilities and infrastructure in SMA N 2 Banguntapan are good enough.

Based on interview with Physics teacher at SMA N 2 Banguntapan, lack of students problem solving skills occurred because students still difficult to use the information which has been obtained to solve the problem. Students often face difficulty if they find a variety of different questions. Based on interview with Physics teacher, most students did not understand the subject of the dynamics of rotation and the kinetic theory of gases. It was because the subject is complex and abstract, so the students hard to understand the concept of kinetic theory of gases. Data showed that students who had not reached KKM to the subject the kinetic theory of gases to $80,36 \%$ and often after attended remedial test.

Based on observation in the class, activity learning still centered on teachers, while students is only listen and make note. So, the learning are in one direction.

One innovatife learning models and can solve the above problems is a cooperative learning model of Auditory, Intellectually, and Repetition (AIR). This learning model assumes that a learning is more effective if attention are focused to three things: Auditory, Intellectually, and Repetition.

Auditory means learn by listening, speaking, presentations, argumentation, express opinions, and responding. Intellectually means thinking skills need to be trained through the exercise of reason, solve problems, construst and implement. Repetition means necessary in learning to the broader and deeper understanding. For example, students need to be trained by working the subject, assignments or quizzes. According to Siti Khadijah, dkk (2013), an emphasis on three things the students will have the capacity more in understanding, creativity, liveliness in droves, the problem solving skills, and a strong memory. This fits in with the research by Hasnawati, dkk (2016) suggested that intellectually in the model of Auditory, Intellectually, and Repetition (AIR) can exercise the students problem solving skills.

\section{MATERIALS AND METHODS}

\section{Study Area}

Characteristics an ideal gas of the kinetic theory of gases is based on the assumtion following (Halliday \& Resnick, 1978: 765-766):

a. A gases consists of particles called molecules.

b. Molecules an ideal gases move at random in all directions. 
c. Molecules an ideal gases spread equally across in all area.

d. Distance between molecules far higher than with the size of the molecules.

e. No interaction inter molecular force.

f. Inter particle collision elastic is perfect.

g. The laws of Newton is valid to the molecule an ideal gases.

1. The Laws of gas

a. Boyle's law

In the 1662, Boyle found the fact that the pressure of a gas always inversely with the volume of gas when temperatures guarded remains constant. This statement can be expressed mathematically:

$$
\begin{gathered}
p \propto \frac{1}{V} \\
p V=\text { konstan }(\text { when } T \text { constant }) \\
p_{1} V_{1}=p_{2} V_{2}
\end{gathered}
$$

b. Charles and Gay Lussac's law

"if the pressure of gas in a closed vessel maintained constant, the volume of gas comporable with the temperatur. Mathematically written:

$$
\frac{V}{T}=\text { konstan } \operatorname{atau} \frac{V_{1}}{T_{1}}=\frac{V_{2}}{T_{2}}
$$

"if the volume of gas in a closed vessel maintained constant, the pressure of gas comnporable with the temperatur".

$$
\frac{p}{T}=\text { konstan atau } \frac{p_{1}}{T_{1}}=\frac{p_{2}}{T_{2}}
$$

c. Boyle-Gay Lussac's law

With join the laws above, obtained relationship as follows:

$$
\frac{p V}{T}=\text { konstan atau } \frac{p_{1} V_{1}}{T_{1}}=\frac{p_{2} V_{1}}{T_{2}}
$$

2. Equation the state of ideal gas

Boyle-GayLussac's law only when for unfolding process, the number particle of gas in the state of remaining. If the number of particle changed, the volume of gas also changed, although pressure and temperatur maintained constant.

$$
p V=N k T
$$

If $N=n N_{A}$, and $N_{A} k=R$, so obtained equation the state og ideal gas as follows:

$$
p V=n R T
$$

3. Pressure and Tekanan dan ideal of gas constant The amount of pressure being done particles of gas against a wall the hall of gas formulated as follows:

$p=\frac{1}{3} \frac{N m \bar{v}^{2}}{v}$ dengan $\bar{v}^{2}=\frac{v_{1}^{2}+v_{2}^{2}+\cdots+v_{n}^{2}}{N}$

Jika $E_{k}=\frac{1}{2} m v^{2}$, maka $p=\frac{2}{3} \frac{N \overline{E_{k}}}{V}$

4. Temperatur and the kinetic energy of ideal gas The relationship temperatur with the kinetic energy of ideal gas:

$\overline{E_{k}}=\frac{3}{2} k T$ atau $T=\frac{2 \overline{E_{k}}}{3 k}$

Thus, it can be concluded that temperature of gas related with the kinetic energy of gas. The higher temperature of gas, the greater the kinetic energy. The kinetic energy in here is the kinetic energy of the average gas obtained from the average of speed.

5. The effective speed of gas

If there are any molecules move with different speeds so an average speed $\left(v_{r}\right)$ and the effectiveness of speed $\left(v_{e f}\right)$ was formulated by:

$$
\begin{aligned}
& v_{e f}=v_{r m s}=\sqrt{\frac{N_{1} v_{1}^{2}+N_{2} v_{2}^{2}+\cdots+N_{m} v_{n}^{2}}{N_{1}+N_{2}+\cdots+N_{n}}} \\
& \text { If } E_{k}=\frac{2}{3} k T=\frac{3}{2} p V=\frac{1}{2} m v^{2}=\frac{1}{2} m v_{r m s}^{2}, \text { so } \\
& v_{r m s}=\sqrt{\frac{3 k T}{m}}
\end{aligned}
$$

6. A degree of freedom gas and a theorem ekipartisi of energy

There are three motion that may be of diatomic molecules, as in this picture.
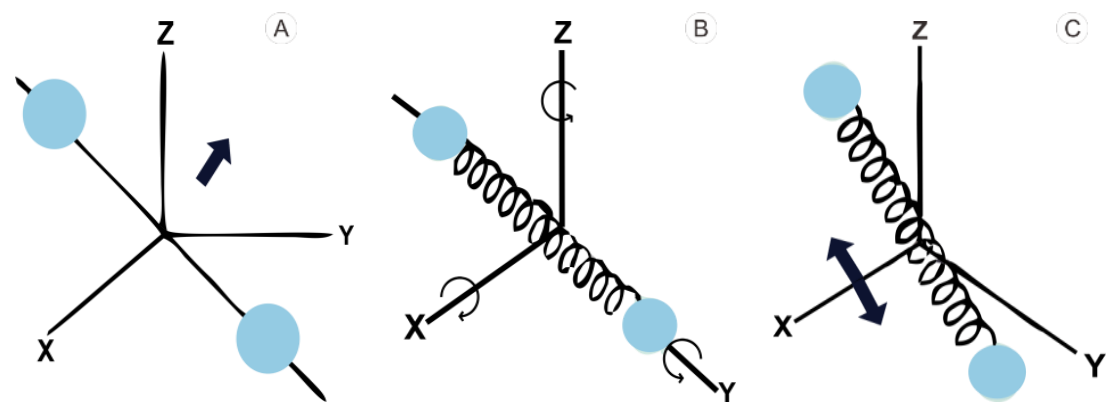

Source: Theory and Application of Physics (Budi Purwanto: 2011)

Figure 1. Three motion that may be of diatomic molecules (A) translation motion (B) rotation motion (C) vibration motion. 
a. Monoatmoic gases having three degree of freedom. The average of kinetic energy from kinetic energy of translation. $E_{k}=\frac{3}{2} k T$

b. For diatomic gases in high temperature $( \pm 1000 K)$ having degree of freedom and the average of kinetic energy from kinetic energy of vibration, translation, and rotation. $E_{k}=\frac{7}{2} k T$

c. Diatomic gas in $\pm 500 \mathrm{~K}$ having five degree of freedom from kinetic energy of translation and rotation. $E_{k}=\frac{5}{2} k T$

d. In low temperature $( \pm 250 K)$ only translation motion, so having three degree of freedom. $E_{k}=$ $\frac{3}{2} k T$

7. Internal energy in ideal gas

Internal energy in a gas is total energy that particles.

The amount of energy for gas monatomic, as $\mathrm{He}, \mathrm{Ne}$, dan Ar is $U=\frac{3}{2} N E_{k}=\frac{3}{2} N k T$.

For diatomic gases, as $\mathrm{H}_{2}, \mathrm{O}_{2}, \mathrm{~N}_{2}$ in low pressure showing result as follows:

a. If low temperature so the internal energy:

$$
U=\frac{3}{2} N E_{k}=\frac{3}{2} N k T
$$

b. If temperatur $\pm 500 \mathrm{~K}$ so the internal energy:

$$
U=\frac{5}{2} N E_{k}=\frac{5}{2} N k T
$$

c. If high temperature so the internal energy:

$$
U=\frac{7}{2} N E_{k}=\frac{7}{2} N k T
$$

\section{Procedures}

a. Pre-Experiment

A field identification. A field identification included school identification and problem solving skills observation in student of grade XI IPA SMA N 2 Banguntapan.

b. Experiment

This section consists of giving pretest, treatment and posttest.

c. Post Experiment

Data analyzed by posttest used calculation statistics. The calculation used to answer hypothesis is accepted or rejected.

\section{Data Analysis}

Test a prerequisite analysis

Test a prerequisite have done by two step, that is normalitas test and homogenitas test

a. Normality test

Normality test used to knows the skor is normal or not. Normalitas test have done with kolmogorovSmirnov test.

$$
D=\max \left|F s\left(X_{\mathrm{i}}\right)-F t\left(X_{\mathrm{i}}\right)\right|
$$

Normaitas test using pretest-posttest score in kinetic theoy of gases. b. Homogenity test

Homogenity test used to knows the variance of data (Sugiyono, 2010: 140). Data were taken from prest dan posttest score. Homogenity test in this research using Levene's test.

$$
W=\frac{(N-p) \sum_{i=1}^{p} N i(\hat{z} i-\hat{z})^{2}}{(p-1) \sum_{i=1}^{p} \sum_{j=1}^{m i}(z i j-z i)^{2}}
$$

c. Hipothesis test

Data analyzed in this research is pretest-posttest skor to know students problem solving. Hipothesis test in this research using t-test (Independent Sample Test). $\mathrm{T}$ test included parametric statistic which can be done by assuming a given data is homogen and normal. (Sarwono, 2009: 125).

$$
t=\frac{\overline{x_{1}}-\overline{x_{2}}}{\sqrt{\frac{\left(n_{1}-1\right) s_{1}^{2}+\left(n_{2}-1\right) s_{2}^{2}}{m_{1}+n_{2}-2}\left(\frac{1}{n_{1}}+\frac{1}{m_{2}}\right)}}
$$

Or

$$
t=\frac{\overline{x_{1}}-\overline{x_{2}}}{\sqrt{\frac{s_{1}^{2}}{n_{1}}+\frac{s_{2}^{2}}{n_{2}}}}
$$

\section{RESULTS AND DISCUSSION}

\section{Results}

This research is a quasi-experimental research and implemented in class XI SMA N 2 Banguntapan in the second semsester of the 2016/2017. The study population is all class in grade XI SMA N 2 Banguntapan consists of four parallel classes namely XI IPA 1 until XI IPA 4 with simple random sampling technique as experiment class is XI IPA 2 (taught by AIR models) and as control class is XI IPA 3 (taught by direct learning models).

The independent variables in this research is AIR learning model and the dependent variables is student problem solving skills.

The design in this study are pretest-posttest control group design as follows.

Table 1. Pre-test Post-test Control Group design.

\begin{tabular}{llll}
\hline Class & Pre-test & Treatment & Posttest \\
\hline Experiment & $\mathrm{O}_{1}$ & $\mathrm{X}$ & $\mathrm{O}_{2}$ \\
control & $\mathrm{O}_{3}$ & $\mathrm{Y}$ & $\mathrm{O}_{4}$ \\
\hline
\end{tabular}

First hipothesis test is to know the effects the treatment in experimental class for students problem solving skills. Data which be could the next analyzed using t-test independent with SPSS 16.0. T-test independent result from students problem solving as follows: 
Table 2. T-test independent students problem solving skills.

\begin{tabular}{llllllll}
\hline Section & Class & \multicolumn{6}{c}{ Result (t-test for equality of means) } \\
\cline { 3 - 8 } & & $\mathrm{N}$ & t-hitung & $d f$ & Sig. (2-tailed) & $\alpha$ & explanation \\
\cline { 2 - 8 } Pretest & Experimental & 30 & \multirow{2}{*}{0,817} & 41,904 & 0,418 & 0,05 & not different \\
& control & 28 & & & & & \\
Posttest & $\begin{array}{l}\text { Experimental } \\
\text { control }\end{array}$ & 30 & 5,780 & 43,990 & 0,000 & 0,05 & different \\
& 28 & & & & & \\
\hline
\end{tabular}

Section pretest showing first skills of two groups that is experimental class and control class. Based on table 2, shows that sig. (2-tailed) amount 0,418. That value greater than significant $\alpha$. From that analysis know that first skills of experimental class and control class before getting treatment is same. That showed that $\mathrm{H}_{0}$ accepted dan $\mathrm{H}_{\mathrm{a}}$ rejected.

Based on table 2, shows that sig. (2-tailed) sebesar 0,000 . That value smaller than significant $\alpha$ so can be concluded that $\mathrm{H}_{0}$ accepted dan $\mathrm{H}_{\mathrm{a}}$ rejected. From the analysis, we knows that the treatment with Auditory, intellectually, and Repetition (AIR) model which given in experimental class affect for students problem solving skills in kinetic theory of gases.

\section{Discussion}

At the auditory, learning started by presentation of material by educator with the methods of talk and show the experiment video. This method accompanied in a manner showing went on experiment material that has learned, it is expected that students will more about matter outlined .

At the intellectually, students divided into 6 group, each group consists of 5-6 students. A subdivision of a group it should be heterogeneous. Any of a group of given problems in LKPD, then every group discuss to solve problems given. At this stage, students trained to understand a problem, plan resolution, implement resolution, and re-examining. After a discussion, representatives one of a group of presented the results in front of.

At the repetition, teacher giving the repetition material that has taught at the meeting by granting quiz.

\section{CONCLUSIONS}

The result showed that (1) Auditory, Intellectually, and Repetition (AIR) learning model influence on problem solving skills of students on the subject of theory kinetic gas (level of significance (sig. 2-tailed) $=0,000<\alpha=$ 0,05 , therefore $\mathrm{H}_{0}$ is rejected and $\mathrm{H}_{\mathrm{a}}$ is received), (2) Auditory, Intellectually, and Repetition (AIR) model learning can improve students' problem solving skills on the subject of theory kinetic gas ( $N$-Gain experimental class $=0,886($ high $)>N$-gain control class $=0,662$ (medium).

\section{ACKNOWLEDGEMENT}

Thank you for all parties had been help and providing support so researchers can be done this research.

\section{REFERENCES}

Abdullah, M. (2011). Physics for Senior High School Grade XI. Bandung: PT penerbit Erlangga.

Azwar, S. (2012). Reliabilitas dan Validitas. Yogyakarta: Pustaka Pelajar.

Halliday \& Resnick. (1985). Fisika Jilid 1 Edisi Ketiga. Bandung: Erlangga.

Huda, M. (2013). Model-Model Pengajaran dan Pembelajaran. Yogyakarta: Pustaka Pelajar.

Meier, D. (2000). The Accelerated Learning Handbook. New York: McGraw Hill.

Polya, G. (1957). How to Solve It. New York: Princeton University Press.

Rosyid, M.F. Romy, H.S.B., Rachmad, R., et al. (2008). Kajian Konsep Fisika 2. Solo: PT Tiga Serangkai Pustaka Mandiri.

Sugiyono. (2013). Metode Penelitian Pendidikan. Bandung: Alfabeta.

Wena, M. (2009). Strategi Pembelajaran Inovatif Kontemporer: Suatu Tinjauan Konseptual Operasional. Jakarta: Bumi Aksara.

Widoyoko, E.P. (2012). Teknik Penyusunan Instrumen Penelitian. Yogyakarta: Pustaka Pelajar. 